\title{
ROLE OF CHILDREN'S HOMES IN REINTEGRATING CHILDREN IN NEED OF CARE AND PROTECTION
}

\author{
Ms. Prerna Singh \\ Ph. D Research Scholar, Department of Sociology and Social Anthropology, Punjabi University, \\ Patiala.
}

DOI: 10.46609/IJSSER.2021.v06i07.010 URL: https://doi.org/10.46609/IJSSER.2021.v06i07.010

\begin{abstract}
Family plays a pivotal role in the primary socialization of the children. But in some instances family turns out to be functionally incapable or unavailable to nurture children. In such instances alternate care in the shape of Child Care Institutes and Children's Homes play an integral role in socializing the children through rehabilitation and reintegration. Children's homes shelter the needy children by providing them standards of care, protection and training. The present research paper is based on the role of Children's Homes in providing essentials of lives to the young, vulnerable child inmates. It was an empirical study conducted in the districts of Patiala, Jalandhar, SAS Nagar, Bathinda, Gurdaspur and Hoshiarpur in the state of Punjab. The study attempts to explore the scope and significance of the Children's Homes besides their contribution in shaping the lives of the children, in need of care and protection. The paper also highlights the impacts of these children's homes on the overall wellbeing of the child and adolescent inmates. The paper also attempts to showcase the gaps between the intended and actual outcomes of policies formulated for the welfare of the child inmates besides suggesting remedial measures to fill these gaps. The research paper is a modest attempt to add to the existing theoretical framework in the associated discipline of sociological assessment and state interventions in the Children's Homes. The need of the hour is to understand and take up the responsibility of ensuring a better today and tomorrow for these children.
\end{abstract}

KEYWORDS: Children in Need of Care and Protection, Juvenile Justice (Care and Protection) Act, Children Homes, Observation Homes, Shelter Homes, Child Welfare Committee

\section{INTRODUCTION}

The future of a nation depends on the overall well-being of its children. The emotional, 
International Journal of Social Science and Economic Research

ISSN: 2455-8834

Volume:06, Issue:07 "July 2021"

physical and mental nourishing of the children is a crucial step towards a developed tomorrow. The patterns of advancement and development can be facilitated as well as hindered by the physical as well as environmental circumstances. As a child advances from one stage to another, the encircling environment, categorically the family plays a significant role in securing the proper growth and development of the child.

The United Nations Convention on the Rights of Child (United Nations, 1989) defines a child under Article-1 as 'a child means every human being below the age of 18 years unless under the law applicable, majority is attained earlier' (Morrow, 2011).

Chapter 1, Section 2 (12) of The Juvenile Justice (Care and Protection) Act 2000 defines a child as "a person who has not completed 18 years of age" (Juvenile Justice (Care and Protection of Children) Act, 2015).

\section{THEORETICAL INSIGHTS}

A review of studies carried out and literature available to the concerned area of research marked importance for the genesis of research design and research process.

Browne discussed that institutional care has an impersonal structure and young inmates usually do not get affection, warmth from the professional staff members because they are not emotionally attached to the young ones in the institutes. Also the staff members working in child care institutes are not skilled and properly trained to do their work (Browne 2008).

Dozier reviewed that children in institutional care have significant deficit in all the domains that have been examined, children's social and interpersonal development is impaired and their cognitive development is delayed. A majority of the child inmates lack emotional attachment those are brought up in institutes at the same time children develop indiscriminately sociable behavior. The children brought up in institutional care has lower cognitive ability (Dozier 2012).

Roger discussed that children primarily face changes in the early eight years of their lives; which include their learning abilities, social interaction with peer and other social groups and role expectation. Their capability to acknowledge to such an effectual and evolving environment directly and indirectly effect their sense of identity and position in the society.

The psycho analytical development of a child marks the shift from childhood to adulthood (Roger 1961). 


\section{International Journal of Social Science and Economic Research}

ISSN: $2455-8834$

Volume:06, Issue:07 "July 2021"

Bowlby (1965) in his study 'Forty-Four Juvenile Thieves' delved upon the importance the mother child bond and held that the mother plays a cardinal role in the primary socializa tion of a child in the early years of his life. Children who are separated from their mothers, remain deprived from motherly love and hence resort to deviant behavior. Maternal passivity is identical in effect to maternal neglect (Haralambos 2000).

Andry claimed in his study 'Parental Affection and Delinquency' (1962) that boys who experience unsatisfactory relationship with their father for any reason account for delinquency in the later stages of their life. The delinquent behavior of an individual is mainly because of his less intimacy with the father. This results in deviant behavior of an individual in the family as well as in the society. Father's relationship is often seen more primarily related to delinquent behavior than that of a mother (Haralambos 2000).

Goffman (1961) in his work 'Total Institutions' explained that re-socialization is the foremost goal of care institutes. Such institutes are set up to cater to the needs of those beings who are incapable to handle themselves. The individual at these institutes are always under surveillance and their activities are constantly monitored. It includes orphanages, shelter homes, children's homes, observatory homes and prisons. These institutes focused upon reshaping a different self of an individual and also act as a training and rehabilitating places (Haralambos 2000).

Primarily, children were believed to be the sole responsibility of the parents as well as the society; but the perspective has transformed into a postulation that parents guard and direct the interests of their children (Hegar, 1989). Humans are not genetically organized to develop into social human beings and hence need proper care and ample socialization entirely from the childhood. During the initial phases of the childhood, a child is fully c ared for and looked after by his/her parents. The constructive role of the parents during the initial phases of childhood hence assumes to be of essentially significant in the long run growth of the child (Senthil and Shanmughavelayutham, 2008).

Though there is an increasing realization that home is the perfect place for children to grow and evolve, yet in some cases home turns out to be functionally incapable to cater to the fundamental nurturing needs of the children due to inescapable factors. One may come across instances where the family is undergoing financial strain or may be unable to look after their children; instances where children suffer from acute physical, and at times mental disabilities and where adequate living standards cannot be maintained or sustained, inevitably leading to a large number of children rendered homeless, physically disabled and mentally deranged and hence abandoned as destitute. Emotionally disturbed, these children 


\section{International Journal of Social Science and Economic Research}

ISSN: $2455-8834$

Volume:06, Issue:07 "July 2021"

become vu lnerable to all sorts of peculiarities, unless they are provided care and protection in the form of alternate care in the society.

The guidelines accepted by the United Nations General Assembly in 2009 promoted the efforts to keep children with their families, where possible. But when a family become dysfunctional either due to poverty or any strain, the need arises for alternate or institutional care. Institutional care can be precised as an organized arrangement of system for children who are routinized with the assistance of adult care. The children in these child care institutes are better looked after in terms of education, health and nutrition and the ir overall development take place. These residential care focus at providing the family atmosphere and care to child inmates in these homes. In terms of security, children in the institutional care are protected from all kinds of exploitation and abuse. Institutional care imparts as a safety valve for all those deprived and destitute children who have no one else to care and look after them. These homes provide an escape from the worst casualties that can otherwise take place. Institutional care provides solution to the complex problems of orphaned, abandoned and needy children. The central responsibility of the state is to formulate the policies and implement laws for protecting the children who are in need of care and protection (UNICEF 2006).

Adoption, foster care and child care institutes are three frequently emphasized alternate remedial measures for disadvantaged and needy children in the society. Adoption and noninstitutional foster care have proved to be the best possible kinds of substitute care for children in need of care and protection, as they could provide closest family and friendly atmosphere to the children to grow. However, these acts of assistance do not seem to be escalating in a developing nation like India due to its prevailing socio-economic conditions (Paul, 1979: 187). Given the socio-economic limitations of a developing nation, residential care has remained to be the elementary form of care for the underprivileged and needy children. The child care institutes and children's homes act as a safety valves for the children who are discarded by the families. These child care institutes provide shelter and standards of care to the worst sufferers of poverty, socially excluded and discriminated children.

During the post-independence spell, the government along with voluntary organisations realized its responsibility towards the disadvantaged sections of the society especially towards children. As per a UNICEF report of 2018, India is a home to 414 million children and 26 million more are born every year - more than any other nation in the world. Presently, child care institutes in the country are run through combined efforts of Government as well as non-Government agencies. The Central and provincial governments 
International Journal of Social Science and Economic Research

ISSN: 2455-8834

Volume:06, Issue:07 "July 2021"

have made and implemented various legislations and policies over the years to safeguard the interests of the children. The financial grants from the Central Social Welfare Board (CSWB) have further assisted in the proper functioning and maintenance of the Child Care Institutes and Children's Homes (UNICEF 2018).

\section{WHO ARE THE CHILDREN IN NEED OF CARE AND PROTECTION?}

The Juvenile Justice (Care and Protection of Children) Act, 2000 of India indicates that children need care and protection mainly in situations where they have risks to their lives or wellbeing, both physical as well as emotional, where there exist such threats or even the mere fear of such threats within the family, outside on the streets or in the society at large. Chapter 1, Section 2 (14) of the Juvenile Justice (Care and Protection of Children) Act, 2015 defines a child in need of care and protection as a child:

(i) who is found without any home or settled place of abode and without any ostensible means of subsistence; or

(ii) who is found working in contravention of labour laws for the time being in force or is found begging, or living on the street; or

(iii) who resides with a person (whether a guardian of the child or not) and such person -

a. has injured, exploited, abused or neglected the child or has violated any other law for the time being in force meant for the protection of child; or

b. has threatened to kill, injure, exploit or abuse the child and there is a reasonable likelihood of the threat being carried out; or

c. has killed, abused, neglected or exploited some other child or children and there is a reasonable likelihood of the child in question being killed, abused, exploited or neglected by that person; or

(iv) who is mentally ill or mentally or physically challenged or suffering from terminal or incurable disease, having no one to support or look after or having parents or guardians unfit to take care, if found so by the Board or the Committee; or

(v) who has a parent or guardian and such parent or guardian is found to be unfit or incapacitated, by the Committee or the Board, to care for and protect the safety and well-being of the child; or 


\section{International Journal of Social Science and Economic Research}

ISSN: $2455-8834$

Volume:06, Issue:07 "July 2021"

(vi) who does not have parents and no one is willing to take care of, or whose parents have abandoned or surrendered him; or

(vii) who is missing or run away child, or whose parents cannot be found after making reasonable inquiry in such manner as may be prescribed; or

(viii) who has been or is being or is likely to be abused, tortured or exploited for the purpose of sexual abuse or illegal acts; or

(ix) who is found vulnerable and is likely to be inducted into drug abuse or trafficking; or

(x) who is being or is likely to be abused for unconscionable gains; or

(xi) who is victim of or affected by any armed conflict, civil unrest or natural calamity; or

(xii) who is at imminent risk of marriage before attaining the age of marriage and whose parents, family members, guardian and any other persons are likely to be responsible for solemnization of such marriage (Juvenile Justice (Care and Protection) Act, 2015).

Section 50 of the Juvenile Justice (Care and Protection of Children) Act, 2015 and its Draft Rules, 2016 outlines the setting up of Children's Homes and outlines their purpose and goals. Sub-section (1) of Section 50 of the Act mandates the State Government to establish and maintain, in every district or group of districts, either by itself or through voluntary or non governmental organisations, Children's Homes, which shall be registered as such, for the placement of children in need of care and protection for their care, tre atment, education, training, development and rehabilitation. Sub-section (2) of Section 50 of the Act provides that the State Government shall designate any Children's Home as a home fit for children with special needs delivering specialized services, depending on requirement. Sub-section (3) of Section 50 of the Act provides that the State Government may, by rules, provide for the monitoring and management of Children's Homes including the standards and the nature of services to be provided by them, based on individual care plans for each child. (Juvenile Justice (Care and Protection) Act, 2015).

The present research paper focuses on the role of children's homes in reintegrating and rehabilitating the children those in need of care and protection. The major parameters on which the functioning of children's homes and their impacts on the child inmates were analysed 
included education and learning outcomes, nutrition and health care, mental health, hygiene and sanitation, and recreation. The study attempts to explore the scope and significance of the Children's Homes besides their role in shaping the lives of the children, in need of care and protection. The research paper attempts to showcase the gaps between the planned and actual outcomes of strategies formulated for the safety and protection of the child inmates besides suggesting remedial measures to fill these gaps. The research paper is a modest attempt to accumulate to the existing theoretical framework in the associated domain of sociological assessment and state interventions in the children's homes.

\section{METHODOLOGY}

The present study was exploratory and descriptive in nature, covering all the vital aspects and effectively addressing the research problem. The sample of the study was drawn from the seven Children's Homes that are registered with Department of Social Security \& Women and Child Development, Government of Punjab. The information was collected from both primary and secondary sources. Primary data was collected through interviews and focused group discussions. Secondary data was drawn from various sources such as books, theses, journals, newspaper articles, official records and various amended and updated editions of the Juvenile Justice (Care and Protection) Act, 2015.

As per the information available, there are seven registered government run Children's Homes in the state of Punjab located in different districts, namely:

\section{Table 1}

Distribution of registered government run children's homes in the state of Punjab

\begin{tabular}{|c|l|c|c|}
\hline $\begin{array}{c}\text { SR. } \\
\text { NO. }\end{array}$ & $\begin{array}{l}\text { NAME OF THE } \\
\text { INSTITUTE }\end{array}$ & $\begin{array}{c}\text { DESIGNATED } \\
\text { FOR }\end{array}$ & LOCATION \\
\hline 1. & Children's Home & Boys & Rajpunda \\
\hline 2. & Children Home Patiala & Boys & Gurdaspur \\
\hline 3. & Children's Home & Boys & Hoshiarpur \\
\hline 4. & Children's Home for Boys & Boys & Dusarna (Mohali) \\
\hline 5. & Children's Home & Boys & Jalandhar \\
\hline 6. & Children Home for Girls & Girls & Jalandhar \\
\hline 7. & Children Home & & \\
\hline
\end{tabular}




\section{(Source: Department of Social Security \& Women and Child Development, Government of Punjab)}

The sample for the present study was drawn through census method on the basis of practical considerations and feasibility of the field work. For the present study sample consisted of all the child inmates residing in the aforementioned Children's Homes in the state of Punjab besides one supervisor from each of these the Children's Homes. Information was collected from each and every inmate selected through the Census method through and Focused Group Discussion (FGDs) and interviews. The researcher tried to get an insight into the existing functioning of the Children's homes in the area under study. Besides the views of child inmates, the supervisors of each Children's Homes were interviewed to gain in depth information.

\section{INSTITUTIONAL PROFILE OF THE CHILDREN'S HOMES IN PUNJAB}

The present study was conducted in all Government -run Children's Homes in the state of Punjab. There are total 7 chi ldren's homes in the state that are located in s ix districts. At the time of study, there were 245 child inmates in these Children' s Homes, of which 100 inmates were boys in children' s homes of Rajpura, Dusarna, Bathinda, Gurdaspur and Hoshiarpur and 145 inmates were girls in the children's homes of Jalandhar. Some of the vital indicators relating to the profile of these Children' s Homes including their locations, staff details, date of inception and legal recognition, and inmate strength have been appended in Table 2 .

Table 2

Table showing the profile of the Children's Homes under study

\begin{tabular}{|l|l|c|c|c|c|c|}
\hline \multicolumn{1}{|c|}{$\begin{array}{c}\text { S. } \\
\text { NO. }\end{array}$} & \multicolumn{1}{|c|}{$\begin{array}{c}\text { NAM } \\
\text { E }\end{array}$} & $\begin{array}{c}\text { STAF } \\
\text { F }\end{array}$ & $\begin{array}{c}\text { NUMBE } \\
\text { ROF } \\
\text { INM ATES }\end{array}$ & $\begin{array}{c}\text { DATE OF } \\
\text { INCEPTI } \\
\text { ON }\end{array}$ & $\begin{array}{c}\text { DATE OF } \\
\text { RECOGNITI } \\
\text { ON }\end{array}$ & $\begin{array}{c}\text { LOCALI } \\
\text { TY }\end{array}$ \\
\hline 1. & $\begin{array}{l}\text { CHILDREN HOME PATIALA, } \\
\text { RAJPURA }\end{array}$ & 11 & 18 & 1980 & 2011 & Urban \\
\hline 2. & CHILDREN HOME, DUSARNA & 11 & 26 & 1975 & 2001 & Rural \\
\hline 3. & CHILDREN HOME, BATHINDA & 14 & 18 & 1979 & 2000 & Urban \\
\hline 4. & CHILDREN HOME, JALANDHAR & 13 & 90 & 1992 & 2006 & Urban \\
\hline
\end{tabular}


International Journal of Social Science and Economic Research

ISSN: 2455-8834

Volume:06, Issue:07 "July 2021"

\begin{tabular}{|l|r|c|c|c|c|c|}
\hline 5. & $\begin{array}{r}\text { CHILDREN HOME FOR } \\
\text { GIRLS, JALANDHAR }\end{array}$ & 15 & 55 & 1992 & 2006 & Urban \\
\hline 6. & $\begin{array}{r}\text { CHILDREN HOME FOR } \\
\text { BOYS, HOSHIARPUR }\end{array}$ & 12 & 16 & 1985 & 2000 & Rural \\
\hline 7. & CHILDREN HOME GURDASPUR & 12 & 22 & 1975 & 2010 & Urban \\
\hline
\end{tabular}

(Source: Fieldwork 2020-21)

FINDINGS OF THE STUDY

The study was conducted in the government run Children's Homes of Punjab with an aim to assess the functioning of the Children's Homes. It included infrastructure facilities, staffing details, standards of care that included education, nutrition, medical care, emotional and social support offered to child inmates in children's homes as reported by supervisors and child inmates. The views of the supervisors on standards of care provided to the child inmates have been mentioned herein.

\section{SIGNIFICANT FINDINGS FROM SUPERVISORS AND CHILD INMATES}

\section{PROVISION OF BASIC ESSENTIALS}

As per the guidelines of the Juvenile Justice (Care and Protection of Children) Act, 2015 the basic essentials for bedding and clothing shall include mattress, cotton bed sheets, pillows, pillow covers, cotton blankets, age and season appropriate clothing for child inmates, miscellaneous articles like slippers, sports shoes, school uniform and socks. In addition to clothing, items for toiletries include hair oil, tooth brush, toothpaste, comb, bathing soap, moisturizer or cold cream (during winters).

As per supervisors and child inmates of children's homes the basic essentials for bedding and clothing included separate pillows, clean bedsheets, cotton blankets, age and need based clothing to the child inmates. The items for toiletries provided to child inmates included toothbrush, common toothpaste, separate hair oil, separate comb, separate bathing soap and mouth wash. The respondents revealed that all the child inmates in the children's homes were not provided with night wear. 42.4 percent of the child inmates were not enrolled in schools and hence were not provided school uniforms and related accessories.

Institutional care contributes positively in the provision of basic essentials to the child inmates. The positive impacts during the study included healthy grooming of the child inmates, their 
International Journal of Social Science and Economic Research

ISSN: 2455-8834

Volume:06, Issue:07 "July 2021"

positive attitude towards personal hygiene, child inmates developed the habit of cleanliness. But still gaps were observed in terms of providing clothing service to the child inmates.

\section{HYGIENE AND SANITATION}

As per the guidelines of the Juvenile Justice (Care and Protection of Children) Act, 2015 the facilities for hygiene and sanitation in children's home shall include sufficient drinking water, proper drainage system, maintenance and cleanliness of the premises, sufficient number of well- lit and airy toilets and bathrooms, daily sweeping and wiping of all floors, proper washing of vegetables and fruits and cleaning of kitchen slabs.

As per supervisors and child inmates of children's homes the facilities for hygiene and sanitation in the children's homes included sufficient treated drinking water, drainage system, cleanliness of the premises, well lit and airy toilets, maintenance of the children's homes, regular sweeping and wiping and special cleanliness in the kitchen area. The study revealed that child inmates of children's homes of Jalandhar were engaged in cleaning activities like sweeping and wiping. Duties were allotted to the child inmates and as per their turn they had to do the assigned tasks.

Institutional care contributes positively in looking after hygiene and sanitation facilities in the children's homes. In terms of hygiene and sanitation, the positive impacts observed were maintenance of cleanliness in all the children's homes, a healthy environment was offered to child inmates and creating periodic awareness related to hygiene. The negative impacts included delay in getting ready for schools due to lack of sufficient number of toilets and bathrooms. Child inmates were burdened due to the lack of adequate staff personnel like sweepers and cooks.

\section{NUTRITION}

As per the guidelines of the Juvenile Justice (Care and Protection of Children) Act, 2015 the facilities for nutrition in children's home shall include four meals in a day, special meals on festivals and Sundays, menu to be prepared by nutritional expert or doctor and to follow minimum nutritional standard for physical growth of child inmates.

As per the supervisors and child inmates in terms of nutrition provisions in the children's home included three wholesome meals a day and special meals served on special occasions. The positive impacts included assured balanced diet to child inmates, satisfaction related to quality and quantity of food served in children's homes. As per the 
International Journal of Social Science and Economic Research

ISSN: 2455-8834

Volume:06, Issue:07 "July 2021"

supervisors, all the child inmates were provided meals as per nutritional standard prescribed under Juvenile Justice (Care and Protection of Children) Act, 2015 . The negative impacts included a compulsion for child inmates of Jalandhar to participate actively in cooking activities, non-availability of sizeable ratio of cooks in all the children's homes and no preference was given for the individual's choices in choosing the menu for meals.

\section{HEALTH AND MEDICAL CARE}

As per the guidelines of the Juvenile Justice (Care and Protection of Children) Act, 2015 the facilities for health and medical care in children's home shall include a medical officer, para medical staff, maintenance of medical record of child inmates, availability of first aid kit and to take preventive measures in the outbreak of infectious diseases.

As per the supervisors and child inmates the facilities for health and medical care in the children's homes included maintenance of medical files and health cards of all the child inmates, in a majority of the children's homes doctor had a regular visit, staff members looked after the child inmates in case of emergency. All the children's homes had availability of first aid kit and extra care to the sick inmates. Apart from providing all the facilities related to health and medical care, all the children's homes lacked ambulatory care and the facility of para medical staff was only available in children's home Dusarna and Bathinda.

Institutional care contributes positively in the provision of medical care included periodic health checkups, optimal patient focused care, provision of first aid kits in the children's homes. The negative impacts included delay in treatment due lack of ambulatory care in the children's homes and over burdening of the staff members due to non-availability of para medical staff in the children's homes.

\section{MENTAL HEALTH}

As per the guidelines of the Juvenile Justice (Care and Protection of Children) Act, 2015 the facilities for mental health in children's home shall include services of trained counselors and abuse free environment for child inmates.

As per the supervisors and child inmates regular counselling sessions were conducted either by the counsellors or supervisors related to children's personality development, behavioural patterns and changes, environmental influences, role of work and career, development of one's identity, stress management and coping with negative life events (if any). The study indicated that the 
International Journal of Social Science and Economic Research

ISSN: 2455-8834

Volume:06, Issue:07 "July 2021"

lack of counsellors in majority of the children's homes had overburdened the work of supervisors in the children's homes. It was difficult for the supervisors to counsel each and every individual separately.

In terms of mental health, child inmates had a positive frame of mind after interactive counselling sessions and these sessions had helped in overcoming and coping up with their tough situations. But at the same time, the overall administrative functioning of the children's homes had suffered due to inadequate number of counsellors in the children's homes.

\section{EDUCATION AND LEARNING OUTCOMES}

As per the guidelines of the Juvenile Justice (Care and Protection of Children) Act, 2015 the facilities for education in children's home shall include age and ability appropriate education within the children's home or outside, range of educational opportunities such as mainstream inclusive schools, bridge schools, open schooling and non-formal education, extra coaching, appoint trainers and experts whenever necessary and to avail scholarships, grants and schemes.

As per the supervisors and child inmates in majority of the children's homes, the child inmates were enrolled in various grades and attaining education. A majority of the children's homes had facility of tutors. The child inmates were time and again counselled to focus on career prospects. As per the supervisors not even a single children's home was availing any scholarship aid for higher studies of child inmates. Absence of tutors in the children's homes of Rajpura, Bathinda and Hoshiarpur had doubled the work of supervisors and staff members. As per the child inmates they shared healthy interaction with their teachers. Child inmates gave a satisfactory response to the quality of education they were attaining from schools.

The child inmates were getting an opportunity to attain education which otherwise was not possible. They got a chance to improve their intellectual skills and made them capable to adjust with outer world. Besides that, the overall grades of child inmates had declined and child inmates had lagged behind due to non-availability of regular teaching aids in the children's homes. At the same time, the overall administrative functioning of the children's homes had suffered.

\section{RECREATION}

As per the guidelines of the Juvenile Justice (Care and Protection of Children) Act, 2015 the recreational facilities in the children's home shall include indoor games, outdoor 
International Journal of Social Science and Economic Research

ISSN: 2455-8834

Volume:06, Issue:07 "July 2021"

games, yoga, meditation, television, picnic, library, educational trips and cultural events.

As per the supervisors and child inmates a majority of the children's homes had facilities of indoor and outdoor games, regular educational trips were organized, facility of library and cultural events were organized. As per the supervisor and child inmates of children's home Jalandhar there was neither outdoor sports facilities nor a playground. The child inmates in this children's home were deprived of picnics, educational and leisure trips and outings.

A variety of activities, sports and games in children's homes made the child inmates healthy and active. It also strengthened the feeling of cooperation, adjustment and team spirit. Celebrating festivals had strengthened community bonds amongst child inmates in the children's homes. At the same time the absence of sports activities hindered the physical growth of the child inmates.

\section{DIFFICULTY IN CATERING NEEDS OF CHILD INMATES}

In majority, the supervisors of the children's homes did not face any difficulty in catering to the needs of the child inmates. The state government was releasing funds time to time and they were wisely utilized in the proper functioning of the children's homes. the supervisors along with staff personnel worked as a unit. As per the supervisors, the child inmates tend to overheard and overlooked basic instructions given to them. In majority of the children's homes the lack of adequate staff members had overburdened the present staff members. The staff members played multiple roles in the children's homes leading to role strain and role conflict. The strength of child inmates was more and comparatively caregivers were lesser in the Children's Homes.

\section{INITIATIVES BY CHILDREN'S HOMES}

As per supervisors, children's homes provided standards of care including shelter, clothing, education, nutrition, hygiene and sanitation and medical aid to child inmates in the children's homes. It's the responsibility of the State to offer facilities and equal opportunities to children within institutions and outside to develop in a healthy manner. As per the supervisors, the best steps had been initiated by them with the help of staff members to make these child inmates part of the mainstream. Child inmates were offered a healthy atmosphere with all possible opportunities that were required for their overall development. The child inmates in the children's homes had social and emotional support of the supervisors and caretakers. The children's homes were making all the possible attempts to see child inmates progressing in their lives.

\section{PROVISIONS FOR REHABILITATION OF CHILD INMATES}

The child inmates in the children's homes were provided care and shelter till the age of 18 years. 
International Journal of Social Science and Economic Research

ISSN: 2455-8834

Volume:06, Issue:07 "July 2021"

After that child inmates were either restored by their family members or they were shifted to State After Care in Ludhiana (boys) and in Amritsar (girls). In these centres, child inmates have their vocational and skill training. As per supervisors the State government with the help of Child Welfare Committee prepared a programme for child inmates who leave children's homes on attaining eighteen years of age by giving them employable training and placing them back into the society. The policies related to rehabilitation of child inmates were implemented by State After Care.

\section{STATE'S CONTRIBUTION IN PROPER FUNCTIONING OF THE HOME}

The state ensures to provide adequate services to child inmates in the shape of children's homes. State government make sure that children's home s provide the minimum standards of care and infrastructural facilities to child inmates. As per the supervisors, state had a major role to play in the proper functioning and maintenance of children's homes. The state government had been releasing funds timely for welfare of child inmates and overall functioning of the children's homes. It had also been conducting meetings at regular interval to had an insight of activities in the children's homes. Children's homes were working smoothing only because of state's active participation in knowing de tails about children's homes and child inmates.

\section{CONCLUSION AND SUGGESTIONS}

In the views of supervisors, the state has a major contribution in proper functioning of the children's homes. Children's homes make continuous efforts for a better tomorrow of child inmates. But, despite the efforts of the state a few gaps have lessened the consistency of work. Firstly, incomplete recruitment of regular staff members had added to work load of existing employees in the children's homes. Secondly, those on contractual basis felt disenchanted as they were over burdened with work and still were drawi ng same pay. At times they did not work whole heartedly and it affected overall functioning of the children's homes. Thirdly, state can initiate regular vocational training courses in children's homes for child inmates so that they get skilled and well trained. For the proper functioning of children's homes regular and skilled staff should be recruited. Fourthly, children's homes of Dusarna and Bathinda were rented buildings and in-charges of homes had requested for permanent infrastructure so that child inmates should be more safe and sound. Children's homes have a commitment to provide standards of care including shelter, clothing, education, nutrition, hygiene and sanitation, medical aid and healthy atmosphere to children in need of care and protection.

\section{REFERENCES}

Morrow, V. 2011. Understanding Children and Childhood. Centre for Children and 
International Journal of Social Science and Economic Research

ISSN: 2455-8834

Volume:06, Issue:07 "July 2021"

Young People: Background Briefing Series, No. 1. Southern Cross University, Lismore, NSW, Australia.

Paul, R. 1979. The Child in India: Formal Programmes; in Gokhale, S.D and Sohini, N.K.(eds.).

Child in India, Bombay: Somainja Publications Pvt. Ltd., 1979.

Roger, C. 1961. On Becoming a Person. A therapist's view on psychotherapy. London: Houghton Mifflin Company.

Senthil, S. \& Shanmugavelayutham, K. 2008. Role of Parents in Early Childhood Care and Development, Journal of School of Social Work, 5(6), 5-9.

Singh, A. 2015. The Juvenile (Care and Protection) Act, 2000: It's Analysis (Unpublished LL.M Dissertation). Punjabi University, Patiala.

Haralambos, M. and R.M. Heald. 2007 . Sociology: Themes and Perspectives. New York:McMillan.

Ibid.

Ibid.

Browne, K. 2009. The Risk of Harm to Young Children in Institutional Care. United Kingdom: Sage Publications Ltd.

Dozier, M. 2012. Institutional Care for Young Children: Review of Litera ture and PolicyImplications. United States: University of Delaware.

UNICEF.2018. For Every Child Every Right. [Internet] [ http://www.unicef.org>file] [Retrieved on December 15, 2019 at $1.25 \mathrm{pm}$.]. 